\title{
EVALUATION OF IMPLEMENTATION OF LEARNING QUALITY ASSURANCE IN SMA MUHAMMADIYAH 2 YOGYAKARTA
}

\author{
EVALUASI PELAKSANAAN PENJAMINAN MUTU PEMBELAJARAN DI SMA \\ MUHAMMADIYAH 2 YOGYAKARTA
}

\author{
Oleh: \\ Desi Arafatun Na'mah \\ Prodi Pendidikan Akuntansi Universitas Negeri Yogyakarta \\ desiarafatunnamah@gmail.com

\begin{abstract}
Abdullah Taman
Staf Pengajar Jurusan Pendidikan Akuntansi Universitas Negeri Yogyakarta abtaman@uny.ac.id
\end{abstract}

\begin{abstract}
The objective of this study is to describe and examine the evaluation of the implementation of the Quality Assurance of Learning Activities is seen in terms of the efforts made to ensure the quality of learning, supporting and restricting factors of quality assurance in activities learning at class XI in SMA Muhammadiyah 2 Yogyakarta. This research uses qualitative descriptive approach. Data were collected through observations, interviews and documentation. Results showed that (1) The efforts that SMA Muhammadiyah 2 Yogyakarta conducted to guarantee the quality of learning activities in class XI were preparation of the learning tools, supervision of class, quality management system ISO 9001:2008, convene a workshops, evaluation of the learning activities, and monitoring of the learning process by the school principal. (2) The factors that support the implementation of the quality assurance activity learning class XI in SMA Muhammadiyah 2 Yogyakarta were the school facilities, involvement of teachers and learners while carrying out the learning process in the class, the encouragement and warning from teachers to students, coordination between the parents of class XI students with the school, the evaluation meeting with the school committee, regular meetings between the head of the SMA Muhammadiyah 2 Yogyakarta with Dikdasmen good area or region.
\end{abstract}

Keywords: Quality Assurance, SMA Muhammadiyah 2 Yogyakarta

\begin{abstract}
Abstrak
Penelitian ini bertujuan untuk mendeskripsikan dan mengkaji tentang Evaluasi Implementasi Kegiatan Penjaminan Mutu Pembelajaran yang dilihat dari segi upaya-upaya yang dilakukan untuk menjamin mutu pembelajaran, faktor pendukung dan faktor penghambat kegiatan penjaminan mutu pembelajaran kelas XI di SMA Muhammadiyah 2 Yogyakarta. Penelitian ini menggunakan pendekatan kualitatif deskriptif. Data dikumpulkan melalui metode observasi, wawancara dan dokumentasi. Hasil penelitian menunjukkan bahwa (1) Upaya-upaya yang dilakukan SMA Muhammadiyah 2 Yogyakarta untuk menjamin mutu pembelajaran kelas XI adalah penyusunan perangkat pembelajaran, supervisi kelas, sistem manajemen mutu ISO 9001:2008, mengadakan workshop-workshop, evaluasi kegiatan pembelajaran, dan pemantauan proses pembelajaran oleh Kepala Sekolah. (2) Faktor yang mendukung implementasi kegiatan penjaminan mutu pembelajaran kelas XI di SMA Muhammadiyah 2 Yogyakarta adalah fasilitas sekolah, keterlibatan guru dan peserta didik saat sedang melaksanakan proses pembelajaran ketika di kelas, pemberian motivasi atau teguran dari guru kepada siswa, koordinasi antara orang tua dari siswa kelas XI dengan pihak sekolah, rapat evaluasi antara kepala sekolah dengan komite sekolah, pertemuan rutin antara kepala sekolah SMA Muhammadiyah 2 Yogyakarta dengan Dikdasmen baik daerah atau wilayah.
\end{abstract}




\section{INTRODUCTION}

It's a duty of our government to create quality of education for our nation, Indonesia. Hence, the government should continue to improve the quality of education in this country. Through the education, the community is capable of being erudite, having high competitiveness, and of course have noble moral. Education also contributes in developing this nation from time to time. Indonesia had, several times, sought to improve its education process through various national education targets formulation. One of the formulations is listed in 1945 Constitutional Laws on article 31 which state that:

1. Every citizen deserves to receive education;

2. Every citizen is obliged to join the basic education and the government is obliged to fund it; as well as

3. The government tends and holds a national educational system that increases faith and piety and noble attitude in order to educate the people.

According to Constitutional Laws No. 20 year 23 about national education system, the national education system itself need to be able to ensure the equity on educational opportunity, improve the quality to face the challenges in accordance with the demand of local, national, and global life change. Needs to be done planned, directed, and sustainable education renewals.

Schools and the government should continue to implement efforts to improve the quality of education in this country because education also contributes in developing our nation from one generation to the next. The Indonesian government has repeatedly tried to sort out the implementation of their education efforts, both the implementation of the curriculum as well as through quality guarantee.

Quality assurance in each school is expected to have a positive impact on school itself, improving the quality of education. Hence, schools as educational institutions must understand about how to run quality assurance efforts so the results can be used as the fundamental of improving the quality to achieve expected objectives. The assurance and increasing quality is not only the responsibility of schools itself, but also the responsibility of the whole community that need to be supported either by the central government, the provincial government, as well as the districts/towns government corresponding to each of their authorities.

The problems raised by the researcher in SMA Muhammadiyah 2 Yogyakarta is for the change of KTSP to Curriculum 2013, it caused the school's lack of readiness to conduct learning activities. As stated in the school's missions, one of which is to improve teachers' and staffs' professionalism and appreciation, but in fact, some teachers are not ready with their teaching materials when teaching and learning process is about to start. Also, some teachers still think that the only learning reference for students is them. On the other hand, the school is applying Curriculum 2013 in which students have to be involved to find out their potentials and teachers should realize that they are just facilitators for the students.

Besides, the school already has wifi connection, but they do not use it maximally. Moreover, the school is about to implement e-learning program, but because the wifi connection cannot reach all parts of the school building yet, the program has not been started.

In addition, the Evaluation of Learning Quality Assurance Implementation was never been held at 
class XI in SMA Muhammadiyah 2 Yogyakarta. Seeing the existence of those condition, then the researcher is interested in doing the Evaluation of Learning Quality Assurance Implementation Class XI in SMA Muhammadiyah 2 Yogyakarta. This research is used to see if the learning quality assurance implementation class XI in SMA Muhammadiyah 2 Yogyakarta has been running well that the achievement of learning objectives.

Objective of this article is to evaluate of implementation activity of learning quality assurance in SMA Muhammadiyah 2 Yogyakarta. Organization this paper as follows: introduction, literature review, research method, results and discussion, and the last is conclusion.

\section{Definition of Evaluation}

Evaluation is one of activities in improving the quality of, performance, or productivity of an institution in implementing programs. Through the evaluation, it will be obtained information about what have been achieved and which have not, then the information is used to repair a program. (Djemari Mardapi, 2004:19).

Evaluation is a process of giving consideration of marks and the meaning of something which are under consideration. Something which been considered can be people, objects, activities, condition, or a certain unity, based on to certain criteria in order to make it does not done haphazardly. Without clear criteria what is done is not a process that can be classified as evaluation. (H. S. Hamid Hasan, 1988: 13).

Evaluation is the process of determining the value of something based on certain criteria, which is within the process covered by the effort of finding out and collect required data/ information as the basis for determining the value of something who are the objects of evaluation, such as the, procedure, proposals, the way, approach, model of a work, outcomes of the program and others. (Nana Sudjana, 1988: 127)

Nana Syaodih (1994: 172) stated that evaluation was the broad, complex and continuous activity to know the process and the outcome of the implementation of an education system in achieving its objectives which have been determined.

A Joint Committee on Standards for Evaluation (Purwanto \& Atwi Suparman, 1999:8) defines evaluation as a process of determining value or the effectiveness of an activity to make a decision.

Stufflebeam dan Shinkfield (in Eko

Putro Widoyoko, 2011:3) stated that:

Evaluation is a process of providing information which can be used as consideration to determine prices and services (the worth and merit) from achieved the point, design, implementation and the impact to help make a decision, help accountability and increase understanding to phenomena. According to the formulation, the core of evaluation is the provision of information which can be used as consideration in decision-making.

Brinkerhoff (in Eko Putro Widoyoko, 2011:4) stated that:

Evaluation is a process that determines the extent to which the cause of education could be achieved. In the implementation of the evaluation there are seven elements to be done, such as 1) the determination of focus will be evaluated (focusing the evaluation), 2) formulation design evaluation (designing the evaluation), 3) the collection of information (collecting information), 4) the analysis and interpretation of information (analyzing and interpreting), 5) making a report (reporting information), 6 management of 
evaluation (managing evaluation), and 7) evaluation to evaluation (evaluating evaluation). Ralph Tyler in Suharsimi Arikunto (2009:3) stated that Evaluation is a process of collecting data to determine how far, in terms of what, and where education goal has already been achieved.

From opinions above, it can be concluded that evaluation is activities of information gathering done systematically and continuously through a measurement to gather, describe, interpret, present information and to determine value or effectiveness for its use as a basic either to make a decision, formalizing policies, or formalizing next program or activities, and also used as consideration to make decisions. The purpose of an evaluation is to obtain accurate and unprejudiced information about a program or activities.

\section{Evaluation Models}

Models in evaluation are usually used to know how far the success of activities is done in order to obtain steps to fix or development of the activities. Models evaluation is design of evaluation developed by evaluation experts, usually called equal to its maker or the evaluation steps. There are many models evaluation developed by experts, which are as follows:

Tyler Model

Conceptually emphasizes the evaluation process directly based on instructional goal that has been set at the same time as teaching preparation, the time when a teacher interacts with students is the basic target in the process of learning. Learning is assessed as being successful, according to Tyler's supporters, when the students who are subjected to the process learning can reach the destinations which are being determined in the learning process.

Tyler's approach is principally stressed on the need of goals in the learning process. This approach is systematic, elegant, accurate, and internally having rational logical approach. Tyler's model is sharply differing between the concept of measurement and evaluation. According to Tyler, knowledge of the measurement and knowledge evaluation are separated and a process in which measurement is only one of several possibilities of ways to support the evaluation.

\section{Stake's Model}

Stake's models emphasizes on the implementation of two fundamental things, (1) description, and (2) judgment; and also differs three steps in evaluation program, (1) antecedents/ context, (2) transaction/ process, and (3) output-outcomes.

According to the Stake, while the Central elevators consider educational programs, they inevitably have to do two comparisons, they are:

a. Comparing the condition of specific programs with evaluation results which occur in other programs, with the same target object.

b. Comparing the results of the implementation of the conditions of the program with the standards presented for the program in question, based on the objectives that will be achieved. Therefore, this Stake model in the Indonesian language is called as name description considerations (Arikunto \& Jabar, 2009:43-44).

\section{Free-of-Goal Evaluation Model}

To do the evaluation with the free of goal model, evaluators need to produce two items of information, namely 1) assessment on the real influence (actual effects), and 2) the assessment of the rated to be requirements profile. If a product has an influence that can be shown in the real and responsive to a requirement, this means that the product is planned positively useful and need to be developed; 
and interpretations to the contrary occurs, if a product, including teaching and learning activities, has no real influence on the students. The free model is the destination point of the development of the evaluation program, in which the objects evaluated are not necessary in connection with any of the object or the subject, but directly to the implications of the existence of the program whether or not the object is useful on the basis of existing needs assessment.

CIPP Model (Context, Input, Process, and Product)

CIPP model is the work of team of researchers, who are members of an organization Committee of Phi Delta Kappa USA, who was chaired by Daniel Stuffle - Beam. This evaluation model is the model that is most widely known and applied by the evaluators. Evaluation of model CIPP also includes models that are not too stressed on the purpose of a program. This CIPP model includes four evaluation focuses, namely as follows:

Context evaluation, is a depiction and specifications about the environment of the program or activity, the needs have not been met, the characteristics of the population and the sample of individuals who are served and the purpose of the program or activity. Evaluation context help plan decisions, determine the needs that would be achieved by programs or activities and formulate the goal of the program or activity.

Input evaluation, help organize a decision, determine the sources that there are alternative, what to take, what plans and strategies to achieve the goal, how procedures work to achieve it. The information collected during the assessment phase should be used to determine the source and strategies within the limitations and obstacles that exist.
Process evaluation is used to detect or predict the draft procedures or the draft implementation during implementation stage, providing information for the decision of the program or activity and as recordings or archive procedure has taken place. Basically the evaluation process to find out the extent to which the plan has been implemented and what needs to be fixed.

Product evaluation is the assessment conducted to measure its success in achievement of the goals that have been set. From the results of the evaluation process is expected to help teachers to make informed decisions regarding the continuance, modification or end of a program or activity, because the resulting data will largely determine whether the program or activity continues, modified, or terminated (Widoyoko, 2011:181-183).

\section{Connoisseurship/ Expert Model}

Expert model is proposed by Esner in 1975. This expert model using data collection, analysis, and interpretation of the data takes place inside the mind of the decision maker. This process occurs, when the decision goes in the brain the decision maker based on a model that he has internalized the organizers based on training and experience. Esner formulations were derived from the twin concept, namely 1) concept of educational experts, and 2) the concept of critique of education. Both the twin concept is borrowed from the domain limit criticism of the artist who equates between education of employment practices and of artists.

\section{Evaluators' Requirements}

According to Suharsimi Arikunto and Cepi Safruddin Abdul Jabar (2009:22-23) to be evaluators, one must meet the following requirements: 
a. Able to carry out, the first requirement to be met by the evaluators was that they should have the ability to carry out the evaluation supported by the theory and skills practice.

b. Carefully, can see the cracks and details of the program or activity as well as part of the program or activity that will be evaluated.

c. Objective, not easily influenced by his personal wishes, in order to collect data in accordance with the circumstances, further able to take conclusions as provided by existing provisions.

d. Patiently and diligently, so that in carrying out the task starts from making the design activities in the form of drafting proposals, drafting instruments, collect data, and drafting reports, no rash and hasty.

e. Carefully and responsibly, that do the job evaluation with full consideration, but if there are still errors made, daring risk over all his mistakes.

\section{Quality Assurance Definition}

According to Suparlan (2005:178)

Quality Assurance is the act of guaranteeing the quality that put more emphasis on process issues. In terms of carrying out the assignment process and the fulfillment of the quality management standards consistently and sustainably so that consumers, manufacturers and other parties interested parties gain satisfaction.

From this definition there are three things that need to be made clear, first about the guarantee, both about the quality and the third about the work done in order to guarantee the quality can be realized. The first thing i.e. about underwriting, originating from the word jamin which means responsibility and if the given prefix-pen and suffix-an (Indonesian terms) will have the sense of bearing. And can be given a sense of responsibility to the trust given by a person against another person in order that interested parties sated (Pius Partanto \&
Dahlan al- Barry, 1994:283).

In order to make it more specific, then the second thing about quality score will be described in detail, because usually someone hard to explain the meaning of quality itself, which is usually associated with an expensive, good stuff and branded. But one thing we can believe in, namely that it is a quality that distinguishes between good and vice versa.

According to Jerome s. Arcaro (2007:75) quality is a structured process to correct the output generated and based on the positive efforts undertaken of individuals. So each individual has a very important role in producing something.

The term quality is also interpreted as a thorough overview and characteristics of goods or services who showed his ability to satisfy the specified or implied needs (Nevizond, 1997:1) in terms of what is given in accordance with the needs of users and reliable. Edward Sallis (2007:19) stated that quality is a dynamic idea, while, a rigid definition is not at all helpful. Thus he defines quality in the two concepts, namely the concepts of absolute and relative concept. According to Usman Husaini (2009) quality has 13 characteristics as follows:

Performance: with regard to the functional aspects of the school.

For example: the performance of the teacher in teaching either, provide convincing explanation, healthy and industrious teaching, or preparing learning materials. A good school's administrative and educational service is indicated by the high grade of learning results, many graduates, less of dropouts, and many students graduated on time. Due to the good performance then that school became a school favorite. Reasonable time: finishes on a reasonable time. For example: starting and ending lessons on time. The right time for tests. The deadline for home work. Reasonable 
time for teachers promoted.

Reliable: the age of excellent service lasting for long time. For example: excellent service which is provided by the school is remain the same through years, the quality of the school remain from year to year. As a favorite school lasts from year to year. The school became a particular defending champion from year to year. Teachers rarely sick. The hard work teachers remain the same from year to year.

Durability: hardiness. For example: despite the monetary crisis, the school still remains, it is not closed. Learners and teachers did not despair and always healthy.

Wonderful. For example: the exterior and interior of the school are laid out interestingly. Garden planted with flowers and well maintained. Teachers create educational media. School's family looks neat.

Human Relations: upholding moral values and professionalism. For example: school family are full of mutual respect, both internal and external school's family, democratic, and appreciate the professionalism.

Easy usage: infrastructure used. For example: school rules are easy to implement. School's ibrary books borrowed and returned on time. Teacher in the classroom is easy to understand the learners. Test questions are easy to understand. Demonstrations are easy to be implemented by learners.

Special form: a particular advantage. For example: there is an excellent school whose almost all graduates are received at the University. Excel with their English. Superior with the mastery of information and technology (computerization). Other ones are superior scientific work, arts or sport.

Certain standards: meets certain standards. For example: schools already meet the minimum service Standards (SPM), schools already meet the minimum standards of the national exam or schools already meet the ISO 9001:2000 or schools already meet the TOEFL with a score of 450 .

Consistency: consistency, constant, or stable. For example: the quality of the school from the first till now is not decreasing as should the participants reached a good mark by school helps (not the real mark). School's family is consistent between the words with deeds. When saying no lie, when promising the promises kept, and if it is believed to not betray.

Uniforms: without variation, not mixed. For example: school uniforms the school clothes and department clothing. Carry out the school rules, not indiscriminate or favoritism.

Able to serve: able to give excellent service. For example: the school provides suggestions and advices boxes that are able to be filled with its best. The school is able to provide its prime services to customers of the school so that all customers are satisfied.

Precision: the precision in the service. For example: the school is able to provide service in accordance with the customer's desire, teachers are not wrong in judging the participants. All the citizens of the school work meticulously. Learning hour in school takes place on time.

Educational institution is a production organization that produces educational services purchased by the consumer; the consumer is mainly are the student or college students. But beside that, there are still many other consumers. If the 
manufacturer is not able to market its product, in this case educational services, it is probably caused by the quality is not acceptable to consumers, provide no additional matter to private individuals, or service is not satisfactory. Then the product services offered will not sell. As a consequence, it will retreat and the educational institutions devotee does not exist so that educational institutions are closed. When the institution is closed because of the inability of the managers, then it would cause a disaster on a society (Buchari Alma, 2008:13). View of the importance of the quality and the large number of demands from the public, then the Government issued law No. 20/2003 on the national education system that includes about quality assurance which is stated in article 35 paragraphs 3 .

Quality assurance is a way of producing products that are free from defects and faults as well as meet the product specifications consistently or produce a product which is always good since the beginning (right first time every time) and made to satisfy its customers. According to experts, quality assurance is a program to undertake monitoring, evaluation and corrective action as a continuous and systematic refinement so that interested parties gain satisfaction.

\section{Steps of Quality Assurance}

Quality assurance steps as efforts to ensure and to improve the quality of upper secondary schools are indispensable; in this case there are a few steps in performing quality assurance, which are: (1) standard designation (2) the implementation and monitoring (3) selfevaluation (4) quality improvement.

\section{Standard Designation}

In PP No. 19 of 2005 about National Education Standards set 8 scope of education standards, which include:

1) Content Standards; is the scope of the material and level of competence which is poured in the criteria about the graduate competence, competence study material subjects and syllabus of learning that must be met by learners at every level and type of education.

2) Process standards; is education standards with regard to the implementation of learning on one unit of education to achieve graduates' standard of competency.

3) Graduates standards of competence; is graduates' ability qualifications include attitudes, knowledge and skills.

4) Standards of educators and educational personnel; is the criteria of pre-office education and the feasibility of physical or mental, as well as in office education.

5) Standards of facilities and infrastructure; is education standards relating to minimum criteria about study room, place of sport, places of worship, libraries, laboratories, workshop, play area, a place of leisure and recreation, as well as other necessary learning resources to support the learning process, including the use of information and communication technology.

6) Standards of Management; is education standards with regard to planning, implementation, and supervision of educational activities at the educational unit level, district/city, province, or national in order to achieve the efficiency and effectiveness of the implementation of education.

7) Financing Standards; is a standard set of components and magnitude of the educational unit operating costs which are valid for one year. 
8) Standards of assessment of education; is national standards of education related to the mechanisms, procedures and instruments of learning outcomes assessment of learners.

\section{Definition of Learning Process}

The term learning in science of education is often referred to teaching or teaching and learning. In English, they are called teaching or teaching and learning.

Learning in article 1 grain 20 ACT No. 20 of 2003 on the National Education System is the process of interaction with educators, learners, and learning resources in a learning environment.

Learning is a preparation that is prepared by teachers in order to attract and provide information to students, so that with preparation designed by teachers can help students in the face of the goal (Dimyati dan Mudjiono, 2009:7).

Learning is an effort undertaken by a person or teacher educators to make students study (Team Developer MKDP curriculum and learning, 2011:128).

While the definition of learning according to Oemar Hamalik (2005:57) is a composed combination include elements of human, material, facilities, equipment, and procedures that interplay achieve learning objectives.

From some sense according to experts it can be concluded that learning is a process of interaction between teachers and learners which contains a variety of activities which aims in occurrence of the learning process (behavior change) on learners. Activities in the learning process are basically very complex. But at its core, include activities of messages delivery (knowledge, values, and skills) to the learners, the creation of conducive environment for educational and learning process, learners and empowerment learners' potential through interaction behavior of educators and learners, where the entire act was implemented gradually.
(Zainal Arifin Ahmad, 2012:12).

\section{Evaluation Stage of Learning Outcomes}

The purpose of education is planned behavior change can be achieved through a process of teaching and learning. The results of the study are the results achieved from the teaching and learning process in accordance with the purpose of education. The results of the study measured to know the objectives achievement of the education so that the results of the study should be in accordance with the purpose of education (Purwanto, 2009:54).

The assessment conducted by the teachers towards learning outcomes is used to measure the level of achievement of competence of learners, as well as used as an ingredient for preparing the progress report on the results of the study, and improve the learning process. The assessment is done consistently, systematically, and programmed by using a test and non-test in the form of written or oral observations, measurement performance, attitude, the assessment of the work in the form of assignments, projects and/or products, portfolio, and self-assessment.

On substance, evaluation is an activity to measure the occurred change in behavior. At this stage the teacher is doing the assessment activities over the learning process that has been done.

Evaluation is a tool for measuring the goal achievement. With evaluation, quantity and quality achievement of the learning objectives could be measured. Instead, because of the evaluation is used as a tool to measure goal achievement, then the measurement of planning and development is the goal of learning.

Evaluation serves as a measurement tool to assess learning outcomes as well as reciprocal feedback in the improvement process of learning, meaning that the learning process that has been 
undertaken, if there is lacks it will seen after making the assessment, the process of learning will further restructure in mastering the material provided at the time the learning process takes place. Evaluation of learning (learning outcomes assessment) consists of assessment of learning (before, during, and after the study), the assessment of the behaviour of students in learning, as well as the results of the learning itself.

Student assessment is one important component in learning which also should be planned. This means that the measuring instrument or the instrument of student assessment needs to be prepared first before learning process is done. In general, the purpose of the study evaluation is to know the effectiveness of the learning process that has been implemented. Drafting instrument of student assessment at the beginning, and not after the learning process finished, will work to clarify the direction of learning.

Student assessment includes the level of students' mastery against the learning objectives, both General and special purposes, both aspects of cognitive, psychomotor or affective (Ahmad, 2012:105).

In the evaluation/assessment of learners' learning outcomes, a teacher must have the following capabilities: (1) being able to choose a question based on difficulty level; (2) is capable of selecting reserved based on the level of distinction; (3) able to correct the problem that is not valid; (4) are able to check the answer; (5) are able to classify learning outcomes; (6) able to cultivate learning outcomes; (7) are able to make interpretations of the trend assessment results; (8) was able to determine the correlation between the reserved based on the results of the assessment; (9) are able to identify the level of variation results assessment; and (10) are able to conclude from the results of the assessment are clearly and logically (Majid, 2011:7).

\section{RESEARCH METHOD}

Suharsimi Arikunto (2003:305) stated that qualitative descriptive study is a method that uses benchmarks as assessment in research. According to Lexy J. Moleong (2002:6) the data collected in the form of words, images, and not numbers. In addition, all collected data will become the key against what has been researched. Descriptive qualitative research approach is used to disclose all the facts that actually occurred in the field during the research progresses, namely about learning quality assurance implementation in SMA Muhammadiyah 2 Yogyakarta class XI month in midFebruary to mid March 2016.

The subjects of this research were headmaster, vice principal of curriculum, and teachers in quality assurance activities learning in SMA Muhammadiyah 2 Yogyakarta. The principal and vice principal of curriculum is the one who has special authority because in taking a policy in the activities of quality assurance of learning in SMA Muhammadiyah 2 Yogyakarta and teachers as the main implementers in the activity guarantee quality learning in SMA Muhammadiyah 2 Yogyakarta. The data in this study was collected by researchers through observation, interviews, and documentation. Data analysis techniques in this study was qualitative analysis.

\section{RESULTS AND DISCUSSIONS}

From the results of research through interviews with some respondents note the efforts done SMA Muhammadiyah 2 Yogyakarta in the quality assurance learning class XI. Here are the efforts undertaken in schools ensure quality learning:

\section{Preparation of the learning tools}

Quality Assurance of learning class XI in SMA Muhammadiyah 2 Yogyakarta, starting from the preparation of instructional tools conducted by master 
class XI in the process of teaching and learning activities, such as silabi, the annual program (prota), semester program (prosem), learning implementation plan $(R P P)$, attendance, register values, and physical evidence of Deuteronomy.

Preparation of the learning tools is very important as it is already stated in PP No.

19 of 2005 about national standards of education with the establishment of 8 scope of national standards of education which the preparation of such learning tools included in 2 standard i.e. standard content and process.

So it can be concluded that, in the aspect of quality assurance study of Class XI in SMA Muhammadiyah 2 Yogyakarta that regarding the preparation of the learning tools already meets the requirements specified in the national standards of education.

\section{Supervision of class}

In addition, in an effort to guarantee the quality of instruction, the school also formed a team of supervision class consisting of the principal, and some senior teachers who are appointed to assess each of the existing learning program at that school.

In PP No. 19 of 2005 about education standards also mentioned about the standard of management. That is the standard the management here is education standards with regard to planning, implementation, and supervision of educational activities at the unit level of education, district/city, province, or is a national in order to achieved the efficiency and effectiveness of the Organization of education, in this case, namely the supervision class.

\section{Quality 9001:2008 \\ Management System ISO}

In its efforts, quality assurance in doing school learning in particular class XI is supported with the implementation of the quality management system ISO 9001:2008 has been applied in SMA Muhammadiyah 2 Yogyakarta. It is as expressed by the head of the SMA Muhammadiyah 2 Yogyakarta that the existence of ISO quality management system, individual agencies are considered educational customers can be served properly.

This is confirmed by Vincent and other' (2003:268-269), posited that the quality management system is defined as a question about how organizations are implementing quality management practices consistently to meet the needs of customers and markets.

In addition, results of research of teacher respondents mentioned that the ISO quality management system is a procedure where the school implements the requirements contained in the Standard formulation of operational procedures (SOP) on any educational activities.

\section{Convene a workshops}

In its efforts in order to improve the competency of the master class XI and its employees SMA Muhammadiyah 2 Yogyakarta, the school also hosts an activity regularly through workshops. In addition to enhancing the competency of the master class XI and employees in General, the workshop also to provide socialization on implementation of ISO quality management system. The existence of such a workshop is expected in terms of school resources can improve its quality in order to support the achievement of the vision/mission school.

This is the same as suggested by Sudarwan Danim (2007:56), namely by involving five dominant factors, that is the leadership of the principal, teachers, students, curriculum, and network cooperation. Where the holding of the workshop-workshop with teachers and employees can be involved to the maximum and hand in hand in the guarantee of 
quality learning and results from the workshop workshop - can be applied in school. Djemari Mardapi (2004:19) mentioned that, evaluation is one of a series of activities to improve the quality, performance, or productivity of an agency in carrying out the program. Implement the evaluation through school board meeting teachers to evaluate the educational activities for one semester. The points emphasized in the discussion in the Board meeting that one teachers about student assessment methods to be made i.e. aspects of cognitive, affective and psychomotor, where the school has implemented a default judgment in accordance with the curriculum of 2013.

\section{Monitoring the learning process by Head of School}

Learning activities in schools in order that runs smoothly and is conducive, in practice the principals always try to keep the atmosphere in every class XI in order to be conducive to the way check or evaluate to each class that felt less conducive at the moment the learning process takes place.

This is supported by the presence of the monitors that are in space the principal so that principals can monitor directly the process of learning in class XI. After the principals know the constraints that occur in the classroom, then the principal need to do an evaluation of the joint meeting with the teachers so that the educational process in accordance with the purpose of education in schools.

The supporting and restricting factors of quality assurance activities in the implementation of learning class XI in SMA Muhammadiyah 2 Yogyakarta are

1. Supporting factor

a. Internal factors

From the description of the data the results of research on internal factors that become advocates in the implementation of quality assurance activities learning class XI in SMA Muhammadiyah 2 Yogyakarta note that the supporting factor is that became the school facilities, the involvement of teachers and learners while carrying out the learning process while in the classroom, and the granting of motivation or rebuke from teachers to students. The school also provides school facilities to support the educational process in the classroom through the LCD, audio visual, CCTV, and wifi. The existence of such facilities, expected to increase the competence of teachers as well as students in the learning process.

b. External factors

From the description of the data the results of research on external factors that become advocates in the implementation of quality assurance activities learning class XI in SMA Muhammadiyah 2 Yogyakarta is known to be a factor that is supporting coordination between the parents of the students of Class XI with the school, the evaluation meeting with the school Committee, regular meetings between the head of the SMA Muhammadiyah 2 Yogyakarta with Dikdasmen areas or regions as well as visits from Dikdasmen to school. The school always maximize its efforts in ensuring quality by involving parties outside school, with braiding communication, cooperation, and managing a good school in a reciprocal relationship between the school with outside parties school.

2. Restricting Factors

a. Internal factors

Based on the description data through interviews with some of the respondents that the internal factors that impede the implementation of the quality assurance activity learning class XI in SMA Muhammadiyah 2 Yogyakarta include: the first obstacles from the side of the teacher, since changes in the curriculum of the curriculum to KTSP curriculum 2013 
all teachers still contended that the teacher is a source of science, there are still teachers who lack the broad aims and do not prepare the material well for learning process in the classroom, teachers are still not able in reporting the results of student assessment or report. From a technical point that inhibit internally is not the occurrence of the cooperation of the homeroom teacher, $B K$, fellow teachers, and parents. Then the third barrier of the students, although already using curriculum 2013 but in fact teachers still fishing the students at the time of the clock, the students of Class XI who tend to see who his teacher, what subjects, how many hours of lessons, and play HP when teachers are implementing the learning in the classroom.

b. External factors

Of the description data through interviews with some of the respondents that the external factors that impede the implementation of the quality assurance activity learning class XI in SMA Muhammadiyah 2 Yogyakarta is most caregivers class $\mathrm{XI}$ which is outside the city of Yogyakarta which resulted in communication between teachers with caregivers to become stunted and impressed to be stoic on the development progress of the child's learning outcomes.
Table 1. Summary of the Discussion

\begin{tabular}{|c|c|c|}
\hline No. & Aspects & Research Results \\
\hline 1 & $\begin{array}{l}\text { The efforts that } \\
\text { SMA Muham- } \\
\text { madiyah } 2 \text { Yog- } \\
\text { yakarta did to } \\
\text { guarantee the } \\
\text { quality of learn- } \\
\text { ing activities in } \\
\text { class XI in } \\
\text { SMA Muham- } \\
\text { madiyah } 2 \\
\text { Yogyakarta }\end{array}$ & 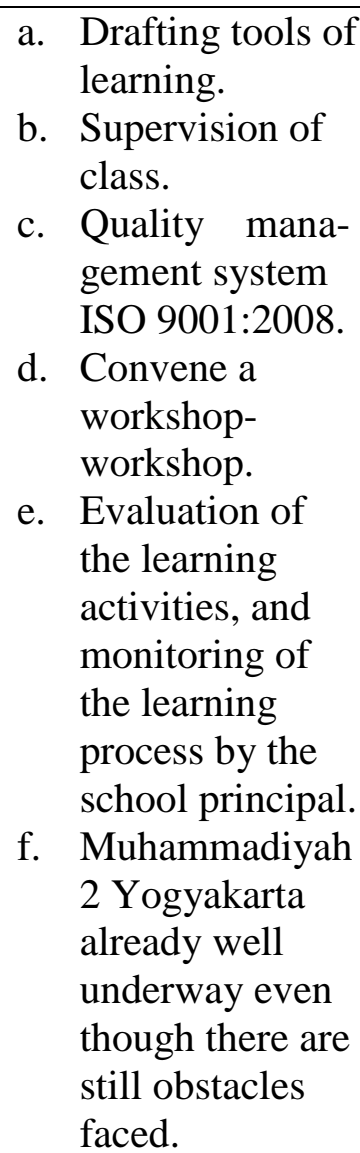 \\
\hline 2 & $\begin{array}{l}\text { Internal factors } \\
\text { that support the } \\
\text { implementation } \\
\text { of quality } \\
\text { assurance } \\
\text { activities } \\
\text { learning class } \\
\text { XI in SMA } \\
\text { Muhammadiyah } \\
2 \text { Yogyakarta }\end{array}$ & $\begin{array}{l}\text { a. School } \\
\text { Facilities. } \\
\text { b. Involvement of } \\
\text { teachers and } \\
\text { learners while } \\
\text { carrying out the } \\
\text { learning process } \\
\text { when in the } \\
\text { class. } \\
\text { c. The granting of } \\
\text { motivation or } \\
\text { rebuke from } \\
\text { teachers to } \\
\text { students. }\end{array}$ \\
\hline 3 & $\begin{array}{l}\text { External } \\
\text { factors that } \\
\text { support the } \\
\text { Implementation } \\
\text { of quality } \\
\text { assurance } \\
\text { activities } \\
\text { learning class }\end{array}$ & $\begin{array}{l}\text { a. Coordination } \\
\text { between the } \\
\text { parents of the } \\
\text { students of } \\
\text { Class XI } \\
\text { with the } \\
\text { school. } \\
\text { b. Evaluation }\end{array}$ \\
\hline
\end{tabular}




\begin{tabular}{|c|c|c|c|}
\hline & $\begin{array}{l}\text { XI in SMA } \\
\text { Muhammadiyah } \\
2 \text { Yogyakarta }\end{array}$ & & $\begin{array}{l}\text { meeting with } \\
\text { the school } \\
\text { committee. } \\
\text { Regular } \\
\text { meetings } \\
\text { between the } \\
\text { head of the } \\
\text { SMA } \\
\text { Muhammadiyah } \\
2 \text { Yogya-karta } \\
\text { with Dikdasmen } \\
\text { areas or regions } \\
\text { as well as visits } \\
\text { from } \\
\text { Dikdasmen to } \\
\text { school. }\end{array}$ \\
\hline 4 & $\begin{array}{l}\text { Internal factors } \\
\text { that impede the } \\
\text { Implementation } \\
\text { of quality } \\
\text { assurance } \\
\text { activities } \\
\text { learning class } \\
\text { XI in SMA } \\
\text { Muham- } \\
\text { madiyah } \\
\text { Yogyakarta }\end{array}$ & $\mathrm{d}$ & $\begin{array}{l}\text { Teachers still } \\
\text { contended that } \\
\text { the teacher is a } \\
\text { source of } \\
\text { knowledge. } \\
\text { There are still } \\
\text { teachers who } \\
\text { lack the broad } \\
\text { aims and do not } \\
\text { prepare the } \\
\text { material well for } \\
\text { learning process } \\
\text { in the class. } \\
\text { Teachers are not } \\
\text { able to make } \\
\text { evaluation } \\
\text { reports for } \\
\text { students. } \\
\text { No coordination } \\
\text { among } \\
\text { classroom } \\
\text { teachers, BK, } \\
\text { teachers to } \\
\text { teachers, and } \\
\text { parents. } \\
\text { Although } \\
\text { already using } \\
\text { curriculum } 2013 \\
\text { but in fact } \\
\text { teachers still } \\
\text { fishing the } \\
\text { students upon }\end{array}$ \\
\hline
\end{tabular}

\begin{tabular}{|c|c|c|}
\hline & & $\begin{array}{l}\text { hours subjects } \\
\text { to take place. } \\
\text { f. Students of } \\
\text { class XI who } \\
\text { tend to see who } \\
\text { his teacher, } \\
\text { what subjects, } \\
\text { what time does } \\
\text { the lesson } \\
\text { underway. } \\
\text { g. Play HP when } \\
\text { teachers are } \\
\text { implementing } \\
\text { the learn-ing in } \\
\text { the classroom. }\end{array}$ \\
\hline 5 & $\begin{array}{l}\text { External } \\
\text { factors that } \\
\text { impede the } \\
\text { implementation } \\
\text { of quality } \\
\text { assurance } \\
\text { activities } \\
\text { learning class } \\
\text { XI in SMA } \\
\text { Muhammadiyah } \\
2 \text { Yogyakarta }\end{array}$ & $\begin{array}{l}\text { Most caregivers } \\
\text { class XI which is } \\
\text { outside the city of } \\
\text { Yogyakarta which } \\
\text { resulted in } \\
\text { communication } \\
\text { between teachers } \\
\text { with caregivers to } \\
\text { become stunted and } \\
\text { impressed to be } \\
\text { stoic on the } \\
\text { development } \\
\text { progress of the } \\
\text { child's learning } \\
\text { outcomes. }\end{array}$ \\
\hline
\end{tabular}

\section{CONCLUSION}

The efforts that SMA Muhammadiyah 2 Yogyakarta did to guarantee the quality of learning activities in class XI were preparation of the learning tools, supervision of class, quality management system ISO 9001:2008, convene a workshops, evaluation of the learning activities, and monitoring of the learning process by the school principal.

Internal factors that support the implementation of the quality assurance activity learning class $\mathrm{XI}$ in SMA Muhammadiyah 2 Yogyakarta were the school facilities, involvement of teachers and learners while carrying out the learning process when in the class, and the granting 
of motivation or rebuke from teachers to students.

External factors that support the implementation of the quality assurance activity learning class XI in $S M A$ Muhammadiyah 2 Yogyakarta were coordination between the parents of the students of class XI with the school, evaluation meeting with the school committee, and regular meetings between the head of the SMA Muhammadiyah 2 Yogyakarta with Dikdasmen areas or regions as well as visits from Dikdasmen to school.

Internal factors that impede the implementation of the quality assurance activity learning class XI in SMA Muhammadiyah 2 Yogyakarta were the teachers still contended that the teacher is a source of knowledge, there are still teachers who lack the broad aims and do not prepare the material well for learning process in the class, teachers are still not able to make evaluation reports for students, no coordination among classroom teachers, counseling teachers, teachers to teachers, and parents. Although already using curriculum 2013 but in fact teachers still fishing the students upon hours subjects to take place, bringing students of class XI who tend to see who his teacher, what subjects, what time does the lesson underway, play HP when teachers are implementing the learning in the classroom.

External factors that impede the implementation of the quality assurance activity learning class XI in SMA Muhammadiyah 2 Yogyakarta was that Most caregivers class XI which is outside the city of Yogyakarta which resulted in communication between teachers with caregivers to become stunted and impressed to be stoic on the development progress of the child's learning outcomes.

\section{REFERENCES}

Ahmad, Zainal Arifin. 2012. Perencanaan Pembelajaran: dari Desain sampai
Implementasi. Yogyakarta: PT

Pustaka Insan Madani.

Arikunto, Suharsimi. 2009. Dasar-dasar Evaluasi Pendidikan. Jakarta: Bumi Aksara.

Arikunto, Suharsimi \& Jabar, Cepi Safruddin Abdul. 2009. Evaluasi Program Pendidikan: Pedoman Teoretis Bagi Mahasiswa dan Praktisi Pendidikan. Jakarta: Bumi Aksara.

Danim, Sudarwan. 2007. Visi Baru Manajemen Sekolah. Jakarta: Bumi Aksara.

Depdiknas. 2008. Sistem Penjaminan dan Peningkatan Mutu Pendidikan (SP2MP).

Fattah, Nanang. 2012. Sistem Penjaminan Mutu Pendidikan dalam Konteks Penerapan MBS. Bandung: PT Remaja Rosdakarya.

Gaspersz, Vincent. 2003. Total Quality Management. Jakarta: Gramedia Pustaka Utama.

Lexy J. Moleong. 2007. Metodologi Penelitian Kualitatif. Bandung: PT Remaja Rosdakarya.

Miles dan Huberman. 1992. Analisis Data Kualitatif. (diterjemahkan Oleh: Tjetjep Rohedi Rosidi). Jakarta: Universitas Indonesia.

Purwanto \& Atwi Suparman. 2009. Evaluasi Program Diklat. Jakarta: Sekolah Tinggi Ilmu Administrasi, Lembaga Administrasi Negara Press.

Republik Indonesia. 2003. UndangUndang RI No. 20 Tahun 2003 tentang Sistem Pendidikan Nasional (SISDIKNAS). Jakarta.

Republik Indonesia. 2006. Peraturan Menteri Pendidikan Nasional Nomor 22 Tahun 2006 tentang Standar Isi untuk Satuan Pendidikan Dasar dan Menengah. Jakarta.

Satori Djam'an, Komariah Aan. 2011. MetodePenelitian Kualitatif. Bandung: Alfabeta. 
Jurnal Pendidikan Akuntansi Indonesia, Vol. XIV, No. 2, Tahun 2016

Desi Arafatun \& Abdullah Taman

$21-36$

Tim Pengembang MKDP Kurikulum dan Pembelajaran. 2011. Kurikulum dan Pembelajaran. Jakarta: PT Rajagrafindo Persada.

Usman, Husaini. 2009. Manajemen: Teori, Praktik, dan Riset Pendidikan. Jakarta: Bumi Aksara, hal. 512-513.

Widoyoko, Eko Putro. 2011. Evaluasi Program Pembelajaran: Panduan Praktis Bagi Pendidik dan Calon Pendidik. Yogyakarta: Pustaka Pelajar.

Zaenal Arifin. 2010. Evaluasi Pembelajaran. Bandung: PT Remaja Rosdakarya. 